\title{
LEYENDO EL MEDIEVO: EL NOMBRE DE LA ROSA
}

\author{
José María Bernardo Paniagua
}

«El texto se nos muestra como un artefacto dual y polémico en el que resulta fundamental la componente estratégica: el enunciador de cualquier proceso discursivo opera una previsión de las representaciones del receptor y sobre ella funda su estrategia; construye unos enunciatarios a los que atribuye conocimientos, deseos, intereses, etc..., y prevé la imagen que el receptor fabricará de él mismo en cuanto a autor y de su estrategia (...). A través del juego de representaciones, atribuciones y actos discursivos el texto va configurando un destinatario y lo va cualificando modal y pasionalmente, en un proceso análogo al de la configuración del autor textual. Recordemos, a este respecto, al Lector Modelo, de Eco" (1).

Quizá sea éste uno de los problemas claves planteados por Umberto Eco en su novela "El Nombre de la Rosa". Efectivamente, dicha obra nos enfrenta, al menos, con una doble realidad: El Nombre de la Rosa (o su autor) como lectura (o lector) de un texto: la cultura (sociedad medieval); lectura, sin duda, semiótica. El lector, o lectores, posibles de "El Nombre de la Rosa" como receptores, destinatarios: lectores individuales partícipes del virtual "Lector Modelo".

Con estas perspectivas arriesgamos nuestra pronunciación, hipoté-

(1) LOZANO, J. et al. (1982): Análisis del discurso, Ed. Cátedra, Madrid, p. 252. 
tica por ahora, en torno a las dos cuestiones planteadas hasta el momento: caracteriza a esta obra de U. Eco - difícilmente delimitada sólo con la denominación clásica de novela (2) - su lectura modélica, sub specie semiotical, de la cultura medieval y en absoluto puede definirse, con una visión parcializada de la estructura superficial, como una novela policíaca recreada en un ambiente medieval (3). Al hacer estas afirmaciones alineamos a $U$. Eco dentro de la visión del mundo medieval que se está imponiendo entre los medievalistas como confluencia de modelos y métodos de lectura (4) de la Historia Marxista, Escuela de los Anales, Historia Total, Nueva Historia, así como de los críticos (formalistas, semiólogos, semióticos) donde la cultura aparece como un macrotexto presentado ante los posibles lectores como pluridimensional y polivalente. Todos ellos reclaman la.presencia de lo alegórico, lo ficticio, lo imaginario, to ideológico, como ingredientes de lectura o, según subraya J. Lozano "Eco, implacable, responde: lo simbólico es una fuerza material como las relaciones de producción" (5).

Sin duda alguna, aunque existe un "programa narrativo", una estructura actancial... acaso no sea lo fundamental para catalogarla unívocamente, puesto que en esta obra encontramos una pluralidad de discursos entrelazados para constituir un discurso de discursos o código de códigos, estructura que incluso en la Edad Media podemos localizar en obras como Le Roman de la Rose (6) y, según el propio U. Eco, constituye algo representativo de la creación contemporánea en su afán de romper los rígidos esquemas de géneros (7).

(2) ECO, U. (1979): Obra abierta, Ed. Ariel, Barcelona, pp. 239 ss.

(3) SITO ALBA, M. (1982): “El Nombre de la Rosa", Los cuadernos del Norte, n. 14 , pp. 42-45.

(4) LE GOFF, J. (dir.) (1978): La nouvelle histoire; Ed. R.E.T.Z.; LE GOFF, J. (1983): Tiempo, trabajo y cultura en el Occidente medieval, Ed. Taurus, Madrid; DUBY, G. (1981): San Bernardo y el arte cisterciense (El nacimiento de/ gótico), Ed. Taurus, Madrid; DUBY, G. (1983): Tiempo de catedrales. El arte y la sociedad, 980-1420, Ed. Argot, Barcelona; VILAR, P. (1974): Historia marxista, historia en construcción, Ed. Anagrama, Barcelona; FONTANA, J. (1982): Historia. Análisis del pasado y proyecto social, Ed. Crítica, Barcelona.

(5) LOZANO, J. (1982): “Umberto Eco: la mirada semiótica", Los cuadernos del Norte, $n$. 14. pp. 46-49, p. 49.

(6) LORRIS, G., MEUN, J. (1974): Le roman de la rose, Ed. Garnier-Flamarion, Paris.

(7) Umberto Eco defiende esta tesis tanto en "Obra abierta" como en aLector in fabula" y en "El Nombre de la Rosa" leemos: al final de mi paciente reconstrucción, llegué a componer una especie de biblioteca menor, signo de la mayor, que habia desaparecido... una biblioteca hecha de fragmentos, citas, períodos incompletos, muñones de libros. 
Desarrollar o verificar estas hipótesis implica: subrayar las líneas básicas para dibujar una biografía de U. Eco productor (semiólogo, semiótico, historiador, crítico, novelista), telón de fondo para poder entender (diccionario, enciclopedia) (8) el mundo intelectual e ideológico del emisor interno en la obra objeto de análisis; acotar, en segundo lugar, y con ayuda de autores diversos (9), los límites textuales, dentro del modelo semiótico, de la cultura medieval; finalmente, ensayar un acercamiento, principalmente semántico, en busca de la visión de la realidad por parte del autor de El Nombre de la Rosa (10), sin marginar, por supuesto, la sintaxis actancial, e intentando descubrir la organización secuencial y "los actos que propician transformaciones en las relaciones intersubjetivas", ni la pragmática para localizar «los aspectos indiciales e instrumentales del lenguaje, es decir, de las situaciones en que se dan los discursos y de los efectos que éstos promueven".

\section{DE LA “OBRA ABIERTA» AL "LECTOR IN FABULA»}

Como productor, U. Eco es polifacético (11), en absoluto indicio de diletantismo o superficialidad, sino más bien, cercano al humanista del Renacimiento 0 al enciclopedista del siglo XVIII. De todas formas, la preocupación por un modelo de lectura crítica de la realidad, del arte, que poco a poco se ha concretado en la Ciencia Semiótica, constituye lo más intenso de su producción intelectual, entendiendo dicha ciencia como epistemología y metodología: el tema común, dice el propio Eco,

Cuanto más releo esa lista, más me convence de que es producto del azar y no contiene mensaje alguno. Pero esas páginas incompletas me han acompañado durante toda la vida que desde entonces me ha sido dado vivir, las he consultado a menudo como un oráculo, y tengo casi la impresión de que lo que he escrito en estos folios, y que ahora tú, lector desconocido, leerás, no es más que un carmen figurado, un inmenso acróstico que no dice ni repite otra cosa que lo que aquellos fragmentos me han sugerido, como tampoco sé ya si el que ha hablado hasta ahora he sido yo o, en cambio, han sido ellos los que han hablado por mi boca. Pero en cualquier caso, cuanto más releo la historia que de ello ha resultado, menos sé si ésta contiene o no una trama distinguible de la mera sucesión natural de los acontecimientos y de los momentos en que los relacionan entre sí (p. 606).

(8) ECO, U. (1981): Lector in tabula, Ed. Lumen, Barcelona, p. 110.

(9) LOTMAN, J. (1979): Semiotica de la cultura, Ed. Cátedra, Madrid; ZUMTHOR, P. (1981), Leggere i/ medioevo, II Mulino, Bologna; SEGRE, C. (1981), Semiotica, historia y cultura, Ed. Ariel, Barcelona; CORTI, M. (1978), Il viaggio testuale, Ed. Einaudi, Torino.

(10) ROMERA CASTILLO, J. (1977), El comentario de texto semiológico, Ed. S.G.E.D.L., Madrid.

(11) PANCORBO, L. (1977): Ecoloquio con Umberto Eco, Ed. Anagrama, Barcelona, p. 19; ECO, U. (1979): pp. 303-305 (1977): Tratado de semiotica general, Ed. Lumen, Barcelona, pp. $15-17$. 
en estas investigaciones, es la relación del arte y de los artistas... ante la provocación del Azar de lo Indeterminado, de lo Probable, de lo Ambiguo, de lo Plurivalente; la reacción, por consiguiente, de la sensibilidad contemporánea en respuesta a las sugestiones de la matemática, de la biología, de la física, de la psicología, de la lógica, y del nuevo horizonte epistemológico que estas ciencias han abierto (12).

Ahora bien, su preocupación semiótica ha privilegiado, en cierto modo, a la cultura medieval como objeto de aplicación de dicho modelo de análisis: U. Eco, dice C. Peña Marín, es un estudioso por simpatía, del medioevo, como de la cultura de masas. Se deja encantar por el objeto que observa, o tal vez estudia precisamente aquello que le fascina. Porque el caso es que el medioevo, por tomar ahora este ejemplo, retorna como una manía en la obra de Eco, como el decorado de las fantasias más queridas donde uno se adentra con la facilidad de hábito. En él transcurre su novela "ll nome della rosa" (13).

Tras esta clara definición científica de U. Eco (14), existe todo un proceso de aprendizaje y afianzamiento evidenciado por la progresiva salida a la luz de alguna de sus obras más significativas a las que nos referiremos a continuación.

Eco rompió el fuego ante el público con "Obra abierta», publicada en 1962, donde, subraya él mismo, un conjunto de ensayos «desarrollan un tema propuesto en una comunicación al XII Congreso Internacional de Filosofía en 1958 titulada «El problema de la Obra abierta». Como objetivo, pretendía "constituir un planteamiento de discusión y como tal deberán leerse. Por ello, no intentarán dar definiciones teóricas válidas para la comprensión de los fenómenos estéticos en general, y tampoco tratarán de pronunciar un juicio histórico definitivo sobre la situación cultural a que se refiere: constituyen solamente el análisis descriptivo de algunos fenómenos de particular interés y actualidad, una sugerencia de las razones que los justifican y una cauta anticipación sobre las perspectivas que abren" (15).

Si bien debe quedar claro, ésta es la preocupación del autor, que «la noción de “obra abierta» no posee valor axiológico. El sentido de estos

(12) ECO, U. (1979): p. 52; PANCORBO, L. (1977): p. 76.

(13) PEÑA, M. C. (1982): "La metamorfosis de Umberto Eco", Los cuadernos del Norte, n. 14, pp. 50-51, p. 50.

(14) PANCORBO, L. (1977): p. 76.

(15) ECO, U. (1979): pp. 50, 77, 89. 
ensayos (aunque haya quien los ha entendido de esta manera, después ha sostenido virtuosamente lo inadmisible de tal tesis) no es dividir las obras de arte en obras válidas (abiertas) y obras no válidas, superadas, malas (cerradas); creemos que ya se ha sostenido bastante que la apertura, entendida como fundamental ambigüedad del mensaje artístico, es una constante de toda obra en todo tiempo" (16).

Las bases empíricas, sus presupuestos e implicaciones de semejante obra los ha resumido Eco diciendo: si se ha podido avanzar la hipótesis de un modelo constante, ha sido porque nos ha parecido advertir que la relación producción-obra-fruición presentaba una estructura similar en casos diversos.

El autor produce una forma conclusa en sí misma con el deseo de que tal forma sea comprendida y disfrutada como él la ha producido. No obstante, en el acto de reacción a la trama de los estímulos y de comprensión de su relación, cada usuario tiene una concreta situación existencial, una sensibilidad particularmente condicionada, determinada cultura, gustos, propensiones, prejuicios personales, de modo que la comprensión de la forma originaria se lleva a cabo según determinada perspectiva individual. En tal sentido, pues, una obra de arte forma completa y cerrada en su perfección de organismo perfectamente calibrado, es asimismo abierta, posibilidad de ser interpretada de mil modos diversos sin que su irreproducible singularidad resulte por ello alterada. Todo goce es así una interpretación y una ejecución, puesto que en todo goce la obra revive en una perspectiva original (17).

Obra Abierta, insistiendo globalmente en sus repercusiones, "sorprendió -indignó o fascinó- por su capacidad de percibir el hecho artístico contemporáneo y de cuestionar la teoría estética a fin de que fuera capaz de aprehender tal fenómeno. Rompe incluso el concepto de obra de arte hasta entonces dominante y permite así que obras inclasificables para la teoría entren en la categoría de artísticas e iluminen además la estructura de otras inspiradas en muy diversos planteamientos" (18).

"Su contenido llamó la atención a miembros de todas las corrientes y hasta el título adquirió cierta agresividad: opera era palabra-clave como toque de atención a los historicistas, aunque resulta aceptable para los

(16) ECO, U. (1979): p. 37.

(17) ECO, U. (1979): pp. 73-74.

(18) PEÑA, M. C. (1982): p. 50. 
estructuralistas; por el contrario, aporta hacía llaga en las estructuras estructuralistas, aunque pudiera ser aceptable para los historicistas" (19).

M. C. Bobes valora en «Obra abierta» el planteamiento de un problema auténtico, pero al carecer de presupuestos suficientes para su solución sugiere "la necesidad de investigar sobre los signos, sobre sus modos de actuar, sobre los códigos sociales, en resumen, sobre la semiología, para sentar las bases que le permitan orientar hacia una solución satisfactoria del problema» (20).

Una insuficiencia epistemológica y metodológica significaron, pues, el decidido camino hacia la semiología-semiótica (21) que, según L. Pancorbo, tiene en el "tratado de Semiótica» un hito fundamental (22), opinión que corrobora M. C. Bobes al subrayar que "los análisis semiológicos necesarios para fundamentar las soluciones irán sucediéndose en La estructura ausente, El signo, Introducción a la semiótica, Tratado de semiótica" (23).

El "Tratado de semiótica general" apareció catorce años después de "Obra abierta"; en él se resumen "ocho años de trabajo y nace de los despojos de otros cuantos libros anteriores" e «intenta reducir a categorías unitarias y —s de esperar- más rigurosas todas mis investigaciones semióticas anteriores, trazando los límites y las posibilidades de una disciplina que se establece como conocimiento teórico sólo para los fines de una praxis de los signos" (24). Su sentido sería —n relación con las demás obras- presentarse como una crítica parcial de sus investigaciones anteriores en relación con los cinco aspectos siguientes:

—Distinguir mejor los sistemas de significación de los procesos de comunicación.

- Intentar introducir dentro del marco semiótico una teoría del referente que antes se habia creído obligado a suprimir por razones de pureza teórica.

(19) BOBES NAVES, M. C. (1982): "Teorías literarias de Umberto Eco", Los cuadernos del Norte, n. ${ }^{\circ} 14$, pp. 32-41, p. 34.

(20) BOBES NAVES, M. C. (1982): p. 34-35.

(21) PANCORBO, L. (1977): pp. 57-58.

(22) PANCORBO, L. (1977): pp. 19-23.

(23) BOBES NAVES, M. C. (1982): p. 34.

(24) ECO, U. (1977): p. 16. 
-Reunir los problemas fundamentales de la semántica y de la pragmática en un modelo único que aspira a resolverlos, ambos, desde un sólo punto de vista.

- Criticar el concepto de signo y el de tipología de los signos.

- Abordar el concepto de iconismo manteniendo la crítica a la afirmación ingenua de que "los iconos son arbitrarios, convencionales y completamente analizables en rasgos pertinentes" (25).

Este objetivo implica reconocer y delínear dos dominios (dialécticamente interdependientes) de una disciplina semiótica: una teoría de los códigos y una teoría de la producción de signos (26).

M. C. Bobes resalta como tesis fundamentales defendidas en el Tratado: la reafirmación de la ambigüedad semántica del texto literario, que ofrece al lector la posibilidad de interpretarlo en formas diversas a través del tiempo y del espacio y la función del lector centrada en su intervención para reducir la multiplicidad semántica, para escoger sus propios recorridos de lectura.

No obstante, esta autora disiente con respecto a Eco del afán por hacer equivalentes autor-lector en el proceso creativo pues para ella "la actividad del autor es creativa y su producto es la literatura; la actividad del lector es interpretativa y su producto objetivado es una teoría de la literatura o un comentario de texto. El mensaje literario parte del autor y se consuma en el lector, pero las relaciones en una y otra dirección no son equivalentes como las presenta Eco en el "Tratado de semiótica General» (27).

Resaltamos (28), tras las acotaciones ya realizadas, que una teoría semiótica general ha de ser capaz de explicar toda clase de casos de función semiótica desde el punto de vista de sistemas subyacentes relacionados por unos códigos. Un proyecto de semiótica general debe comprender una teoría de los códigos y una teoría de la producción de signos; la segunda teoría considera un grupo muy amplio de fenómenos, como el uso natural de los diferentes lenguajes, la evolución y transformación de los códigos, la comunicación estética, los diversos tipos de interacción comunicativa y el uso de los signos para mencionar cosas y estados del mundo.
(25) ECO, U. (1977): p. 17.
(26) ECO, U. (1977): p. 18.
(27) BOBES NAVES, M. C. (1982): 38.
(28) ECO, U. (1977): pp. 26-31. 
Debe realizar también un análisis del concepto de signo para distinguir los signos de los "no signos" y llegar a traducir el concepto de signo por el de función semiótica a fin de poder distinguir entre significación y comunicación, de modo que la semiótica de la significación esté relacionada con la teoría de los códigos y la semiótica de la significación con la teoría de la producción de signos.

Hay sistemas de significación ( $y$, por tanto, código), cuando existe una posibilidad establecida con una convención social de generar funciones semióticas, independientemente de que dichas funciones sean unidades discretas llamadas signos o grandes porciones del habla, con tal de que la correlación haya sido establecida precedente y preliminarmente por una convención social.

Hay proceso de comunicación, cuando se aprovechan las posibilidades previstas por un sistema de comunicación para producir físicamente expresiones y para diferentes fines prácticos, pero, las reglas de tal proceso sólo puede estudiarlas una teoría de la producción física de los signos en la medida en que se hayan codificado previamente.

Al final del Tratado, y conectando ya con el próximo libro, intenta acotar el tema del sujeto de la semiótica: desde el momento en que se afirma que el trabajo de producción de signos constituye una forma crítica social entra definitivamente en escena un fantasma... se trata del sujeto humano en cuanto actor de la práctica semiótica. Su lugar en el marco teórico de la producción de signos donde se da una relación pragmática entre emisor y destinatario que constituye la base para cualquier investigación sobre la naturaleza de los actos comunicativos no ha de ser el de una ficción metodológica, sino también y sobre todo, como "sujeto arraigado en un sistema de condicionamientos históricos, biológicos, psíquicos, tal como lo estudian el psicoanálisis y las ciencias del hombre».

"Lector in fabula" es el último paso hacia la elaboración de su lectura semiótica de la obra artística y/o de la realidad. Es, como dirá M. C. Bobes, obra de cierre del tema, al menos por ahora, puesto que recordamos «la semiótica es una disciplina joven y se desarrolla cada día».

"Cuando en 1962, anota U. Eco localizando intelectualmente su obra, publiqué 'Obra abierta' me planteé el siguiente problema: ¿cómo una obra de arte podía postular, por un lado una libre intervención interpretativa por parte de sus destinatarios y, por otro, exhibir unas caracteristicas estructurales que estimulaban y al mismo tiempo regulaban el orden de sus interpretaciones? Como supe más tarde, ese tipo de estudio correspondia a la pragmática del texto 0 , al menos, a lo que en la 
actualidad se denomina pragmática del texto; abordaba un aspecto, el de la actividad cooperativa, en virtud de la cual el destinatario extrae del texto lo que el texto no dice (sino que presupone, promete, entraña e implica lógicamente), llena espacios vacíos, conecta lo que aparece en el texto con el tejido de la intertextualidad, de donde este texto ha surgido y donde habrá de volcarse: movimientos cooperativos que, como más tarde ha mostrado R. Barthes, producen no sólo el placer, sino también, en casos privilegiados, el goce del texton.

"Cuando - subraya más adelante- vuelvo a considerar desde cierta distancia el trabajo realizado antes me doy cuenta de que el problema de la interpretación de sus libertades y de sus aberraciones ha estado siempre presente en mi discurso... Podría afirmarse que todos los estudios que he realizado entre 1963 y 1975 apuntaban (si no exclusivamente, al menos en gran parte) a buscar los fundamentos semióticos de esa experiencia de apertura a la que me había referido en 'Obra abierta' pero cuyas reglas no había proporcionado".

No obstante, todo este material insistía en la relación entre el usuario de un sistema semiótico y el código, o entre el código y el mensaje. La temática del texto, de su generación y de su interpretación, quedaba soslayada.

Por estas razones - concluye Eco- cesta larga introducción era necesaria para explicar por qué ahora reúno en un discurso orgánico una serie de estudios, escritos entre 1976 y 1978, sobre la mecánica de la cooperación interpretativa del texto. En la actualidad, las investigaciones de semiótica textual han alcanzado tal grado de difusión y refinamiento que sería arduo y reprobable arrojarse a ellas sólo para no sentirse rezagado. Por eso, en estos estudios realizo un doble movimiento: por un lado, me conecto (...) con estas motivaciones 'antiguas' a las que me refería, pero, por el otro, asumo como dato y conocido lo que en estos últimos diez años se ha dicho sobre el texto, $y$, a veces, intento avanzar un poco más: intento articular las semióticas textuales con la semántica de los términos y limito el objeto de mi interés sólo a los procesos de cooperación interpretativa, soslayando... la temática generativa" (29).

Eco en esta obra establece una terminología (30) clave para delimitar

(29) ECO, U. (1981): pp. 13-20.

(30) Las nociones más importantes introducidas por U. Eco en la obra "Lector in fabula" son las siguientes: interpretante (pp. 42, 48, 49), ground (pp. 44, 46), estructuras discursivas 
el instrumental científico de la estructura del texto y la lectura del mismo. Texto que, dice, puede definirse como "un artificio sintáctico semántico - pragmático cuya interpretación está prevista en su proyecto generativo... Sin embargo, para aclarar esta definición conviene representar un texto como un sistema de nudos o de juntas e indicar en cuáles de esos nudos se espera y se estimula la cooperación del Lector Modelo" (31). Tal como aparece, dicho texto "en su superficie lingüística, representa una cadena de artificios expresivos que el destinatario debe actualizar" (32).

La necesidad de actualización continua define al texto como algo incompleto, bien porque, como cualquier objeto lingüístico, oración o término, sigue siendo un flatus vocis mientras no se le pone en correlación, por referencia a determinado código con su contenido establecido por convención: en este sentido, el destinatario se postula siempre como el operador (no necesariamente empírico) capaz, por decirlo así, de abrir el diccionario a cada palabra que encuentra y de recurrir a una serie de reglas sintácticas preexistentes con el fin de reconocer las funciones recíprocas de los términos en el contexto de la oración (33).

Aquí se enclava su teoría del lector modelo, lector que actualiza la gran cantidad de elementos "no dichos» en la superficie del texto por medio de ciertos movimientos cooperativos, activos y conscientes encaminados tanto a la actualización de correferencias, operaciones extensionales, actualización de su enciclopedia, trabajo de inferencia, etc. Afirmaciones todas que nos llevan a caracterizar texto y lector: el texto está plagado de espacios en blanco, de intersticios que hay que rellenar; quien lo emitió preveía que se los rellenaría y los dejó en blanco por dos razones. Ante todo, porque un texto es un mecanismo pereceso (o económico) que vive de la plusvalía de sentido que el destinatario introduce en él y sólo en casos de extrèma pedantería, de extrema preocupación didáctica o de extrema represión el texto se complica con redundancias y especificaciones ulteriores. En segundo lugar, porque, a medida que pasa de la función didáctica a la estética un texto quiere dejar al lector la iniciativa interpretativa, aunque normalmente desea ser interpretado con un margen suficiente de univocidad. Un texto quiere que alguien lo ayude a funcionar... Un texto postula a su

(126 ss.), estructuras narrativas (145 ss.), estructuras actanciales o ideológicas (pp. 245, 248-50), topic (p. 125), isotopia (133, 143-144), trama (146), fábula (pp. 145-146).

(31) ECO, U. (1981), p. 96.

(32) ECO, U. (1981): p. 73 
destinatario como condición indispensable no sólo de su propia capacidad comunicativa concreta, sino también de la propia potencialidad significativa. En otras palabras un texto se emite para que alguien lo actualice; incluso cuando no se espera (o no se desea) que ese alguien exista concreta y empíricamente (34).

Desde esta concepción de lector-destinatario como lector modelo, abstracción de los lectores individuales y, teniendo en cuenta que el código que utiliza el autor no coincide necesariamente con el de los lectores y que el ground del autor no coincide con el de los interpretantes de los lectores, a pesar de los artificios de fijación y unificación del texto, resulta inevitable que las lecturas sean diversas, quedando así justificada teóricamente en el proceso de la comunicación literaria, la existencia de interpretaciones diversas sobre un mismo texto y la libertad del lector se convierte en algo obligado, inevitable y perteneciente a los rasgos inherentes a lo literario.

El texto, a pesar de seguir las estructuras discursiva, narrativas, referenciales, actanciales o ideológicas que lo fijan y limitan con no menor rigidez que las formas, está plagado de no-dichos, de relaciones potenciales que no están en la expresión y que deben actualizarse en el momento de interpretar el contenido. El lector desde su competencia, va dando sentido a los indicios que es capaz de ver, pero no es seguro que los vea todos, ni siquiera que todos los lectores vean los mismos, o que en el conjunto de lecturas se agoten todos: la obra sigue abierta a nuevas interpretaciones.

En todas estas afirmaciones está latente/patente, como afirma Eco que «nunca se da una comunicación meramente lingüística, sino una actividad semiótica en sentido amplio, en la que varios sistemas de signos se completan entre sím (35). Es decir, U. Eco intenta en todo momento y de forma obsesiva una mirada semiótica por encima de la simplemente lingüística, narrativa, etc., así lo ha entendido J. Lozano cuando leyó la obra global de Eco con el título “Umberto Eco: una mirada semiótica».

En dicho trabajo sostiene como tesis que: lo que observamos no es en rigor "hechos" (cosas, fenómenos) sino significados o, dicho con otras palabras, los hechos no son entidades brutas, sino que están definidas por el lenguaje (de la ciencia). O aún más, los objetos, los

(33) ECO, U. (1981): 73-74.

(34) ECO, U. (1981): pp. 76-77.

(35) ECO, U. (1981): p. 78. 
comportamientos, los valores funcionan como tales porque obedecen a leyes semióticas (36).

De ahí deduce cómo Eco "convencido de la vocación ecuménica de la semiótica... el arte, la estética, los mass media, la política, el ceuilletón, la filosofía, la música, la arquitectura, la literatura, las órdenes monacales, el terrorismo, los laberintos, los textos, las plantas del medioevo, la naturaleza, el libro, son vistos por Eco, como a él le gusta decir, subspecie semioticae" (37).

En conclusión, la semiótica, tal como la concibe Eco, pese a ocuparse de cualquier sistema de signos, no pretende sustituir la utopía renacentista de disponer de una ciencia universal que resolviera todos los problemas. Sin embargo, sí trata de dar cuenta de los mecanismos fundamentales, de las leyes generales a partir de las cuales el hombre es capaz de intercambiar signos y comunicar, y todavía más - en un sentido más restrictivo- de las leyes más generales de las relaciones de reenvío (Jacobson). Por tanto se puede decir que, en última instancia, la observación semiótica puede ocuparse de cualquier cosa que pueda ser considerada como signo. $Y$ para Eco es signo toda cosa que pueda ser considerada como sustituto significante de otra... semiosis ilimitada (38).

\section{LA ESTETICA MEDIEVAL}

Además de semiótico, a la vez, y, a veces, sobre todo, U. Eco es apasionado medievalista (39) que, según anota C. Peña - Marín «es un estudioso por simpatía del medioevo... el medioevo retorna como una manía en la obra de Eco, como el decorado de las fantasías más queridas donde uno se adentra con la facilidad de hábito" (40).

Eco ha dedicado mucho tiempo al estudio de la Edad Media, incluso obtuvo la licenciatura de Filosofía por la Universidad de Turín con una tesis sobre "El problema estético en Santo Tomás de Aquino". Posteriormente, en 1959 y al tiempo que publica los primeros ensayos de "Obra abierta" colaboró con su trabajo "Sviluppo dell'estetica medie-

(36) LOZANO, J. (1982): p. 46.

(37) LOZANO, J. (1982): p. 47.

(38) LOZANO, J. (1982): p. 49.

(39) CLARK, H. R. (1983): aln the Renaissance Tradition», Time (diciembre, 12).

(40) PEÑA, M. C. (1982): p. 50. 
vale" en el primer volumen de la obra colectiva "Momentu e problemi di storia dell'estetican.

Alusiones, introducidas como referencias, aparecen en diversas obras suyas e incluso se ha valido de su conocimiento del medievo para, trasplantándolo en el tiempo, leer la realidad actual (41) a la luz del espejo medieval, como puede verse en su trabajo: «La Edad Media ha comenzado ya", del libro colectivo "La nueva Edad Media" (42). También publicó en 1973, la introducción a la edición italiana de «ll Beato de Liébana" (43).

Recogemos, a continuación, algunos rasgos significativos de la producción de $\mathrm{U}$. Eco en torno al medievo por cuanto constituye una de las claves de interpretación (enciclopedia) de "El nombre de la Rosa", pues en los textos citados veremos un cierto análisis parcial de la Edad Media o la emisión de juicios globales.

En «Obra abierta" por ejemplo, aporta una visión de conjunto de la época medieval. En un primer texto nos acerca a la teoría artística de la Edad Media y dice «tenemos otro ejemplo: en el medioevo se desarrolla una teoría del alegorismo que prevé la posibilidad de leer las Sagradas Escrituras (y seguidamente también la poesía y las artes figurativas) no sólo en su sentido literal, sino en otros sentidos: el alegórico, el moral y el anagógico. Tal teoría se nos ha hecho familiar gracias a Dante pero hunde sus raices en San Pablo (videmus nunc per speculum in aenigmate, tunc autem facie ad faciem) y fue desarrollada por San Jerónimo, San Agustín, Beda, Scoto Eriugena, Hugo y Ricardo de Saint Victor, Alain de Lille, San Buenaventura, Santo Tomás y otros, hasta el punto de que constituyó el fundamento de la poética medieval. Una obra así entendida es sin duda una obra dotada de cierta «apertura"; el lector del texto sabe que cada frase, cada figura, está abierta sobre una serie multiforma de significados que él debe descubrir... pero en este caso apertura no significa en absoluto 'indefinición' de la comunicación 'infinitas' posibilidades de la forma; libertad de fruicción; se tiene sólo una rosa de resultados de goce rígidamente prefijados y condicionados, de modo que la reacción interpretativa del lector no escape nunca al control del autor... El significado de las figuras alegóricas y de los

(41) CLARK, H. R. (1983).

(42) ECO, U. et al. (1974): La nueva Edad Media, Ed. Alianza, Madrid, pp. 7-34.

(43) ECO, U. (1982): «Beato de Liébana, el Apocalipsis y el Milenió, Los cuadernos del Norte, n. 14, pp. 2-20. 
emblemas que el medieval encontrará en sus lecturas está fijado por las enciclopedias, por los bestiarios y por los lapidarios de la época; el simbolismo es objetivo e institucional» (44).

A continuación y en otro texto nos ofrece la visión del mundo que tenían los hombres de la época a la hora de plasmarla artísticamente: ... esta poética de lo unívoco y de lo necesario supone un cosmos ordenado, una jerarquía de entes y de leyes que el discurso poético puede aclarar en varios niveles, pero que cada uno debe entender en el único modo que es posible, que es el instituido por el logos creador. El orden de la obra de arte es el mismo de una sociedad imperial y teocrática; las reglas de lectura son reglas de gobierno autoritario que guían al hombre en todos sus actos, prescribiéndole los bienes y ofreciéndole los medios para realizarlos.

La obra conclusa, afirma en otro lugar, y univoca del artista medieval, reflejaba una concepción del cosmos como jerarquía de órdenes claros y prefijados. La obra como mensaje pedagógico, como estructura monocéntrica y necesaria (incluso en la misma férrea construcción interna de metros y rimas), refleja una ciencia para la cual lo real puede evidenciarse paso a paso sin imprevistos y en una sola dirección, procedente de los primeros principios de la ciencia, que se identifican con los primeros principios de la realidad (45).

En su trabajo sobre el desarrollo de la estética medieval persigue, como sin duda, diversos objetivos, pero acaso el más importante sea un intento desmitificador respecto al concepto, valoración y disfrute del arte en la Edad Media por parte de autores significativos - clérigos fundamentalmente- $y$, en cierto modo, del pueblo, intentando convencer a sus lectores de una tesis hoy posiblemente asumida por muchos medievalistas: la modernidad de la Edad Media, en algunos casos revolucionaria, en cuanto peldaño imprescindible para la moderna o contemporánea sociedad.

Todos los presupuestos (objeto, localización, método de su trabajo, quedan explícitos en el siguiente texto: il presente saggio prende in esame nel loro sviluppo storico i problemi e le principali soluzioni elaborate dalla cultura del medioevo latino dal VI al XV secolo della nostra era. Con l'espressione "medioevo latino" intendiamo la filosofia scolastica e l'ambiente gravitante intorno a essa ... (su finalidad es) vedere in

(44) ECO, U. (1977): pp. 76-77.

(45) ECO, U. (1977), pp. 77, 89 
somma come le teorie estetiche abbiano costituito risposte efficaci agli interrogativi posti dalle sperienze di fruizione e produzione del bello propie all'uomo medievale...

Questa impostazione della ricerca risponde già all'obbiezione polemica per cui nel medioevo non sarebbe esistita una dottrina estetica e sarebbero stati elaborati solo aridi e vaghi concetti metafisici nonche confuse affabulazioni allegoristiche (46).

Resalta, a continuación la tesis de concebir la estética de un modo ni dogmático, ni reduccionista que traicionarían la propia historia medieval, para defender un planteamiento - virtualmente semiótico y antropológico - como base de toda su visión de la estética medieval, en función de la cual traza la evolución desde los intereses más tradicionales hasta planteamientos más modernos y debatidos que tendría como pasos claves los siguientes: vedremo dunque como l'estetica medievale, dall'acoblimento piuttos to acritico di temi della tradizione classica venga via via sviluppando, atraverso una metafisica ed una gnseologia del bello, una nozione organica del valore estetico che segna il suo punto massimo di maturità; e como in seguito, declinando questa nozione col disgregarsi dei concetti metafisici tradizionali, essa si apra ad una serie di inquietudini asistematiche circa il concetto di arte e la natura dell'atto poetico, che non trovano giustificazione nei quadri aristotelici e preludono alle dottrine manieristiche dell'ingegno e dell'imaginazione (47).

Hecho semejante recorrido y tras haber analizado lo intimo de cada problema a fin de individualizar las líneas de desarrollo, el cambio de visión y el acrecentarse de un planteamiento crítico y científico en el tema de la estética medieval entendida como la solución que una época ha dado a los problemas estéticos en consonancia con su propia sensibilidad y la de su cultura (48) llega a las siguientes conclusiones:

- La Edad Media no significó, tampoco en la teoría estética, una ruptura con el mundo clásico, por tanto, la consabida línea evolutiva clasicismo - renacimiento, tras el vacío medieval, es, cuando menos, incoherente (49).

- La Edad Media legó a la Edad Moderna un bagaje de cultura esté-

(46) ECO, U. (1959): Sviluppo dell'estetica medievale, Ed. Marzorati, pp. 116-118.

(47) ECO, U. (1959): p. 117.

(48) ECO, U. (1959): p. 117.

(49) ECO, U. (1959): p. 212. 
tica filtrado a través de su particular visión del mundo: desde una estética pitagórica del número que reaccionó ante el desorden de épocas bărbaras, se pasó a una estética humanística, receptora de los valores del arte y las bellezas transmitidas desde la antigüedad que expresa el renacimiento del mundo carolingio. A partir de aquí y con la garantía de un orden político estable, elaborando el sistema de un orden teológico del universo, superada la crisis del año Mil, la estética se hace filosofía del orden cósmico bajo la inspiración de autores como Eriugena. Mientras Europa se cubre de un «blanco mantel de iglesias", las cruzadas revolucionan la vida provinciana del hombre medieval, las luchas comunales le dan una nueva conciencia civil, la filosofía se abre al mito de la naturaleza en primer lugar y al sentido científico de las cosas naturales después y, lo bello, se convierte en un atributo perteneciente a las cosas individuales y no al orden abstracto. Los teólogos del siglo XIII convierten a Cristo en el prototipo de la imagen artística de belleza resplandeciente. Las catedrales reflejan el mundo de las Sumas donde todo está en su puesto: Dios y la corte celestial, la anunciación y el juicio, la muerte, los misterios, etc. Tras este culmen de la cultura medieval preocupada por fijar las esencias estables de las cosas en una fórmula clara y quizás en el seno de esta misma cultura, comienza a replantearse la rigidez y estaticidad del orden reflejado en Sumas, catedrales, enciclopedias, etc., para iniciar una nueva visión más. dinámica tanto de la realidad como del arte (50).

- La estética escolástica, no obstante ha respondido a las tendencias y a la sensibilidad de su época e incluso el verbalismo e idealismo de la estética medieval expresan a su vez la mentalidad dualística de la época y su continua tensión entre el teórico deber ser y las contradicciones cotidianas (51).

-Ante la visión estética medieval sugiere Eco aprender diversas lecciones: puede ofrecer categorías formales para leer con nuevas intenciones. Puede sugerir junto a la tradición griega el ideal de una nueva belleza y un sentido de la armonía y de la racionalidad tal como el que apareció en las filosofías naturalistas. Puede indicar a quien quiera entender esta lección medieval el modo de conectar la antigua y la nueva concepción del arte. Puede mostrar insospechables afinidades parciales con el pensamiento oriental. Puede corroborar una visión ar-

(50) ECO, U. (1959): pp. 212-213.

(51) ECO, U. (1959): p. 213. 
tesanal del arte frente a un arte alejado del sentimiento. Puede inspirar metodologias críticas de gran exigencia y rigor (52).

Su estudio de "El Apocalipsis" puede ser paradigmático para los medievalistas. En él ofrece una lección de investigación histórica y, a la vez semiótica: lectura abierta de una obra siguiendo lo que el texto sugiere y lo que determinó al texto en su proceso de creación (53) así como lo que el lector/es fueron haciendo como destinatarios.

El postulado teórico que apoya su trabajo es el siguiente: un texto es una sucesión de formas significantes que esperan ser rellenadas: los resultados de este relleno son casi siempre otros textos.

Esto sentado, intentará dilucidar el entramado de una lectura continuada y productora que "cuando se escribe, no tiene ninguno detrás - se refiere al Apocalipsis de San Juan- (54) al que 'diremos con blasfematoria mordernidad' denomina obra abierta que sobrevive y durante todo el tiempo que sobrevive, tiene enfrente millares de intérpretes. La lectura que tales intérpretes hacen de él genera otros textos que no son sino paráfrasis, comentarios, utilizaciones parciales, traducciones a otros signos, palabras, imágenes, incluso música (55).

Pues bien, el Beato Liébana -como lector del texto apocalíptico de Juan- «se nos revela como un maestro por defecto de originalidad y exceso de buena voluntad". Admite hacer obra de antólogo colocando juntos todos los comentarios que hombres más ilustres que él han dejado escritos ... (56). Pero, sin saberlo ha introducido sus propias innovaciones.

Este texto, a pesar de que «la lectura no resulta agradable y para la interpretación es ingrato" (57), es un libro aceptado, leído, reproducido por sus contemporáneos, probablemente porque uagrade a sus contemporáneos la mediocridad", o "porque tiene la capacidad de hacer penetrar el discurso cultural precedente, construyéndose un mundo ajeno a la realidad: algo que satisface al hombre medieval en general y que debia de ser aún más aceptado en un período en el que la realidad

(52) ECO, U. (1959), pp. 213-214.

(53) LOZANO, J. (1982): pp. 45-52.

(54) BIBLIA DE JERUSALEN, Ed. Desclee de Brouwer, Barcelona, pp. 1.639-1.660.

(55) ECO, U. (1982): p. 2.

(56) ECO, U. (1982): pp. 2-3.

(57) ECO, U. (1982): p. 4. 
era mucho más insoportable; o quizá por los temas tratados: herejía, venida del Anticristo. Razones todas internas al texto, estructurales, según resalta $U$. Eco: realmente, como veremos más adelante, la aceptación de un texto acaba siendo explicada incluso por cualquier cosa que está fuera del texto; hay un por qué de la interpretación que no reside del todo en el circulo limitado de las interpretaciones (58).

De todas formas, "debe haber una razón por la que la Edad Media prefiera leer a Beato en lugar de a otro autor, o más bien, para que opte por leer, a través de Beato, el Apocalipsis, en vez del Cantar de los Cantares: hay que entender la Edad Media como una sociedad completa y no sólo como un grupo de doctos, porque Beato, al menos a través de la historia de sus ilustraciones, acaba siendo un fenómeno de masas. Veremos enseguida, en el curso de nuestro discurso sobre Beato, que más allá de las razones teológicas y del gusto por la tradición simbólica, existen también razones materiales, ligadas a los ciclos de las culturas y al censo de la población (59).

Analizando más en profundidad el texto, U. Eco resalta las características del relato como autor-intérprete medieval que:

- Se mueve como por un lado con una suerte de empirismo teórico, pasando con desenvoltura de una interpretación a otra, citando una auctoritas como indiscutible y falsificando al mismo tiempo sus palabras, acogiéndose a un padre ilustre cuando le resulta cómodo e ignorándolo cuando encuentra alguna otra interpretación que le parece más suasoria. Por otro, está absolutamente convencido de interpretar (leer) iluminado por la gracia divina, y toma su interpretación por la única posible, apoyándola con pruebas que parecen pretender el rigor científico tal como hoy lo concebimos (60).

- Encarna una típica tendencia medieval para la que la imaginación -incluso la teológica - es eminentemente visual, teniendo en cuenta que pensar a través de imágenes era la forma más socorrida e incluso la única posible, dado el amplísimo analfabetismo de hacer comprender y memorizar el texto sagrado (61).

Todo esto lleva a la siguiente conclusión: el texto de que se habla constituye la superación de un registro visual que traduce e interpreta

(58) ECO, U. (1982): pp. 4-5.

(59) ECO, U. (1982): p. 5.

(60) ECO, U. (1982): p. 8.

(61) ECO, U. (1982): p. 9. 
un texto escrito. El texto escrito pretende reducir a una lectura codificada un texto precedente, escrito en griego ( $y$ anteriormente en hebreo), pero conocido por Beato únicamente en la versión latina, texto que a su vez representa en parte la reinterpretación de los textos precedentes a los que está unido por la común adhesión al género literario de la "revelación". Entre el texto original y el de Beato media una tradición de lecturas interpretativas. A su vez, el texto de Beato estimula otras interpretaciones y genera una tradición apocalíptica que, tras haber impregnado el pensamiento medieval, se transmite en la forma más impensada hasta nuestros dias. Paralelamente, en un juego de influencias frecuentemente concatenadas el registro visual engendra una tradición iconográfica propia que se puede rastrear de forma filológicamente exacta durante la Edad Media y en cualquier caso hasta el siglo XVI (62).

Las razones, según U. Eco que Beato pudo tener para escribir dicho libro pudieron ser: o bien un problema teológico: el antiadopcionismo; o bien debido a la idea de la llegada o presencia del Anticristo y la consecuente o contemporánea expectación del final de los siglos. Realmente, parece ser la preocupación milenarista la razón fundamental, de tal manera que los lectores, reales o posibles, de Beato se enfrentaban a la inminencia del milenio como un hecho histórico incontrovertible: período exacto en que florecen los legendarios terrores del año Mil. Legendarios terrores porque, aunque parezca que nadie se aterrorizó la última noche del milenio, es evidente, sin embargo, que se alzó un vendaval de preocupaciones en la cultura europea antes e inmediatamente después del año Mil, es decir, en la época en que las miniaturas mozárabes retomaban el texto de quien doscientos años antes había discutido tan puntillosamente el problema del fin de los tiempos (63).

En este contexto, interpretado de forma distinta en diversos momentos está claro que, al menos, el año Mil presenta este contraste: por un lado políticos y teólogos que construyen una nueva organización europea; y mientras, por abajo, zonas de sombra, debilidades inmensas, oleadas de descorazonamiento y miedo: el año Mil (...) ofrece un cuadro enérgicamente contrastado. Si ningún texto permite afirmar que, en aquellas capas oscuras, todo se removió por el miedo al fin del

(62) ECO, U. (1982): pp. 11-12.

(63) ECO, U. (1982): p. 14 
mundo, no por eso el miedo, un miedo mal definido que lo satura todo, lo ha sacudido menos (64).

Producido como texto, "cadena de artificios expresivos que el destinatario debe actualizar" el Beato se escinde en dos partes, como si texto e ilustraciones tomaran dos caminos independientes (65).

«El texto sigue una senda solemne: comentario entre los más difusos de un libro sagrado que otros volverán a comentar proporcionándole filiaciones múltiples.

Por su parte, las ilustraciones toman un camino más real, que les hace asumir un puesto preeminente en la evolución del arte figurativo medieval. Las ilustraciones siguen los caminos de Santiago" (66).

\section{CULTURA MEDIEVAL: OBJETO SEMIOTICO}

A modo de puente dentro del proceso de nuestro trabajo entre los planteamientos teóricos en torno a la semiótica, el análisis-de la estética medieval o del mundo de la Edad Media en general y el último punto o la ficción sobre esta época que representa El Nombre de la Rosa, intentando, además, hacer ver que U. Eco no es un extravagante en su empeño de leer semióticamente la cultura medieval aportaremos brevemente el testimonio de algunos autores que han realizado, o se han propuesto realizar, o han proporcionado el instrumental necesario para una lectura similar.

El discurso teórico que subyace a todos estos intentos o realizaciones es la calificación de la cultura como un texto que lógicamente, implica la interrelación - interdisciplinaridad de las ciencias de la cultura: antropología, etnología, sociología y las del lenguaje: lingüística, crítica ... y que produce, acaso, un nuevo concepto, modelo y método de análisis tanto de la cultura como del propio texto. Conocida esta problemática se presentarán los intentos de lectura semiótica de la Edad Media.

J. Lozano en su trabajo "Introducción a Lotman y a la escuela de Tartu» resume el estado de la cuestión en torno a la cultura como texto apto para ser leído desde la semiótica como modelo epistemológico, centrando sus referencias a la semiótica rusa, pionera en este planteamiento (67).

(64) ECO, U. (1982): p. 16.

(65) ECO, U. (1981): p. 73.

(66) ECO, U. (1982): p. 18.

(67) LOTMAN, J. (1979). 
La incorporación -anota hablando de las bases del problema- de la teoría de la información se refleja, al pasar del análisis de la literatura al estudio de lo que él llama "tipología de las culturas", en su concepción del sistema de signos que es la cultura como «información no hereditaria, que recogen, conservan y transmiten las sociedades humanas" o "memoria no hereditaria expresada en un determinado sistema de obligaciones y prescripciones" (68).

La semiótica de la cultura, pues, globalmente ha de preocuparse de la tipología de las culturas —zona en que la semiótica se encuentra en la antropología cultural- donde se incluyen: los comportamientos sociales, los mitos, los ritos, las creencias... Pero a la hora de caracterizar lo semiótico de una cultura es necesario definir la cultura en su relación con el signo que, según Lotman, está situado en el seno de una colectividad donde se intercambia información, es el equivalente material de los objetos, de los fenómenos y de los conceptos que expresa.

Para que un fenómeno cualquiera pueda convertirse en signo, es decir, en portador de un determinado significado, debe formar parte de un sistema para poder establecer una relación tanto con el no-signo como con otro signo. Por tanto, el signo no puede ya reducirse a la mera relación significante-significado, sino que debe entenderse como una unidad cultural entera y la cultura ha de funcionar y caracterizarse como un sistema de sistemas organizados de un determinado modo.

La organización de este sistema que es la cultura aparece a la luz como una suma de reglas y de restricciones impuestas al sistema, base de su diferencia con "la naturaleza" y punto de partida para el establecimiento de una tipología. Además, lleva consigo la posibilidad de considerar la cultura como una lengua: sistema semiótico ordenado de comunicación que sirve para transmitir información; si bien la cultura sería un lenguaje secundario o "sistema de modelización secundaria" (69), puesto que a partir de las lenguas naturales se conforman los sistemas culturales.

La cultura aparece, pues, como un sistema de lenguaje cuyas manifestaciones concretas son textos de esa cultura, de forma que si el mundo es un texto su conocimiento exige un tipo de análisis filológico-textual. Pero, evidentemente, es un texto plural, formado por muchas lenguas, dado que la actividad cultural cotidiana no consiste

(68) LOZANO. J. (1979): “introducción a Lothman y a la escuela de Tartu» en LOTMAN, J. (1979), pp. 21-27.

(69) LOZANO, J. (1979): p. 24. 
más que en: traducir un cierto sector de la realidad a una de las lenguas de la cultura: literatura, arte, sin embargo, la cultura, como objeto semiótico, es un mecanismo plurilingüe, donde se entrelazan códigos diversos: verbal, icónico, sonoro, etc.

Clasificada la cultura, sistema de lenguajes cuyas manifestaciones concretas son textos, en función de su transmisión o aprendizaje nos ofrece dos tipos fundamentales: culturas textualizadas y culturas gramaticalizadas. Las primeras se caracterizan por ser «el resultado de la enseñanza de un determinado comportamiento en que predomina el ejemplo y fundan la cultura como suma de textos que se orientan hacia una expresión", en cambio, las gramaticalizadas "fundan la cultura en cuanto metatextos. Se orientan sobre el contenido. Predomina la ley".

Estos dos tipos de cultura no deben ser considerados necesariamente opuestos. Por ejemplo, es cierto que la cultura textualizada no tiende a distinguir un metanivel particular —las reglas de su propia constitución- ni tiende a autodescribirse - características éstas de la cultura gramaticalizada-; si, posteriormente en la cultura textualizada se introducen reglas, éstas, señala Lotman, son "apreciadas menos que los textos" (70).

La cultura como texto debe analizarse siguiendo un proceso determinado, proceso que ha sido entendido de modo diverso, lo cual, nos presenta un panorama bastante amplio de opciones para una crítica de la cultura. Lotman, que en este punto se distanció relativamente del modelo jakobsiano o comunicativo, ha optado por la semiótica textual que «explica el estudio de la cultura como fenómeno sígnico que hace suponer que lo normal, precisamente es que los que intercambian información no usen un código común sino dos diferentes que hasta cierto punto se interseccionan. Así, el acto comunicativo no es una transmisión pasiva de información sino una traducción, una recodificación del mensaje. El receptor debe reconstruir el mensaje transmitido, por lo que la incomprensión, la comprensión incompleta etc., no son productos laterales del intercambio de información debidas al ruido, a algo no inherente a la comunicación, sino que corresponde a su esencia real». Esta opción caracteriza a la cultura - sistema de signos- como «la tensión constante entre dos polos opuestos, estatismo/dinamismo, unidad/pluralidad: si la heterogeneidad de su organización interna es una ley necesaria para la existencia de toda cultura, no menos necesaria es la unidad, que la cultura logra a través de

(70) LOZANO, J. (1979): p. 27. 
la autoconciencia ... la cultura es generadora de estructuralidad y el lenguaje natural es el que desarrolla, precisamente, esta función de dar nombre, organizar, estructurar la realidad dentro del marco de su culturas (71).

Entendida así la cultura atendremos derecho a examinar la totalidad de los textos que la constituyen desde dos puntos de vista distintos: una comunicación determinada, y el código mediante el cual se descifra dicha comunicación en el texto.

El análisis de la cultura desde este punto de vista nos asegura que es posible describir los diversos tipos de cultura como tipos de lenguajes particulares y que, de esta manera, pueden aplicárseles los métodos usados en el estudio de los sistemas semióticos.

Nos vemos pues, en la necesidad de subrayar que los textos reales de las distintas culturas, por lo general, necesitan no ya de un código determinado para descifrarlos, sino un sistema complejo que tiene una organización jerárquica y a veces nace tras una conjunción mecánica de varios sistemas más sencillos.

De todos modos, en esta compleja compaginación, uno de los sistemas de codificación inevitablemente asume un papel dominante" (72).

A partir de estos presupuestos se han diseñado cuatro tipos de cultura a tenor de los códigos dominantes:

- Cultura donde el código dominante es un modo de organización únicamente semántico.

- Cultura donde domina un modo de organización sintáctico.

- Cultura organizada de modo asemántico y asintáctico.

- Cultura donde el código dominante es una síntesis de el modo semántico y el sintáctico (73).

La cultura medieval, según Lotman, corresponde al tipo semántico y se basa en la semantización (o incluso, simbolización) tanto de la realidad que rodea al hombre como a sus componentes.

Predomina en este tipo de modelización de la realidad la idea de que "en principio fue la palabra" y el mundo es imaginado como palabra, funcionando el acto de la creación como formación de un signo. La

(71) LOZANO, J. (1979): pp. 29-31.

(72) LOTMAN, J. (1979): pp. 41-43.

(73) LOZANO, J. (1979): p. 33. 
conciencia medieval divide tajantemente al mundo en dos grupos contrapuestos: el de los fenómenos con significado y el de los fenómenos de la vida práctica, cuya existencia no tenía valor alguno.

El modelo medieval del mundo quitaba todo el derecho de existir a enormes niveles de vida y colocaba al hombre en una situación contradictoria: sus realidades social y biológica no tenían puntos de contacto. Como ser viviente, no podía aspirar a determinar algunos resultados prácticos de sus acciones, mientras que como ser social debía despreciar las cosas y aspirar a los signos, de tal manera que los acontecimientos prácticos, deseados o temidos, simplemente no existían.

La sociedad medieval era una sociedad con un alto grado de signicidad y en esto basaba su concepción del mundo: cualquier forma de actividad de un colectivo medieval, para ser un hecho con valor social, tenía que transformarse en un ritual. El combate, la caza, la diplomacia, el arte, exigían un ritual.

El signo tenía importancia por su función de sustitución, lo cual resaltaba inmediatamente su doble naturaleza: al sustituto se le consideraba contenido y al sustituyente expresión. Por ello, el sustituyente no podía tener valor autónomo sino que recibía el valor según el lugar jerárquico de su contenido en el modelo general del mundo. La parte, en este modelo, es homeomorfa al todo; no es fracción del conjunto, sino un símbolo suyo y, puesto que el plano del contenido de todo el mundo en su conjunto y de cada valor suyo cultural en particular pertenece a las esencias inconmensurables e indivisibles, cualquier división interesa solamente al plano de la expresión.

Esta relación expresión —contenido y parte- todo lleva consigo muchas implicaciones en el mundo real o cultural de la Edad Media: la lectura, por ejemplo, en el sentido medieval no es acumulación de textos leídos sino penetración continua y reiterada en la estructura del único texto. Persona, sujeto jurídico unidad relevante de otros sistemas sociales: religioso, moral, estatal, eran los organismos corporativos de distintos tipos: los derechos jurídicos o la ausencia de éstos dependían del hecho de si el hombre formaba parte o no de un grupo. La esperanza en el bienestar del más allá estaba ligada a la pertenencia a los grupos de cristianos, de los justos, etc.; cuanto más importante era el grupo del que formaba parte el hombre, tanto más alto era su valor personal.

Todo el conjunto de las oposiciones semánticas particulares, dada la fundamentación de la visión medieval en el principio paradigmático y no en el sintagmático, tendía a reducirse en antítesis culturales fundamentales: cielo-tierra, eterno-temporal, salvación-ruina, bien-pecado, 
las cuales a su vez se reducian a series semánticas, que a un nivel más abstracto podian reducirse a una única oposición semántica fundamental de la cultura (74).

En esta línea de planteamiento: la cultura como texto y el texto necesariamente leído de modo semiótico-semiológico, con mayor o menor conciencia o precisión, podemos encontrar alusiones diversas en por ejemplo, Duby, cuando en la obra "San Bernardo y el arte cisterciense" subraya cy la creación artística, a la que los campeones de la dialéctica han prestado su apoyo, se convierte en exornatio de una palabra. Pues, ¿qué otra cosa puede tener por objeto sino el acendrar y organizar una semiótica del universo?» (75). Idénticas alusiones es posible encontrar en la obra de C. Segre "Semiótica, historia y cultura" y en la de M. Corti "ll viaggio testuale", pero sin duda alguna, la aportación más interesante y la invitación más lúcida a que los historiadores de la Edad Media empleen la semiótica en sus investigaciones la ha realizado Zumthor en su obra «Leggeril medioevo».

\section{EL NOMBRE DE LA ROSA: APOCALIPSIS Y MODERNIDAD}

Umberto Eco por medio de Adso, criatura narrativa suya, nos transmite su perplejidad ante el medievo que, en el tiempo del relato, camina entre los temores apocalípticos y la necesaria modernidad: cuanto más releo esta lista, más me convenzo que es producto del azar y no contiene mensaje alguno. Pero esas páginas incompletas me han acompañado durante toda la vida que desde entonces me ha sido dado vivir, las he consultado a menudo como un oráculo, y tengo casi la impresión de que lo que he escrito en estos folios, y que ahora tú, lector desconocido, leerás, no es más que un centón, un carmen figurado, un inmenso acróstico que no dice ni repite otra cosa que lo que aquellos fragmentos le han sugerido, como tampoco sé ya si el que ha hablado he sido yo o, en cambio, han sido ellos los que han hablado por mi boca. Pero en cualquier caso, cuanto más releo la historia que de ello ha resultado, menos sé si ésta contiene o no una trama distinguible de la mera sucesión natural de los acontecimientos y de los momentos que los relacionan entre sí. $Y$ es duro para este viejo monje, ya en el umbral de la muerte, no saber si la letra que ha escrito contiene o no algún sentido oculto, ni si contiene más de uno, o muchos, o ninguno.

Pero quizás esta incapacidad para ver sea producto de la sombra que

(74) LOTMAN, J. (1979): pp. 43-54.

(75) DUBY, G. (1981): p. 115; SEGRE, C. (1981); CORTI, M. (1978); ZUMTHOR, P. (1981). 
la gran tiniebla que se aproxima proyecta sobre este mundo ya viejo (76).

La respuesta a la perplejidad citada se realiza, por parte de Eco, con mayor originalidad, y quizá coherencia, que en los autores anteriormente señalados. Simplemente, ha querido leer el medievo usando un modelo de lectura que en la Edad Media era comportamiento lector normal a la hora de entenderse o, mejor dicho, a la hora de enseñar quién poseía tal prerrogativa, esto es, el lenguaje de la alegoría y de la ficción, porque "nunc videmus - dice Adso- per speculum et in aenigmate y la verdad, antes de manifestarse a cara descubierta, se muestra en fragmentos ..., mezclada con el error de este mundo, de modo que debemos deletrear sus fieles signáculos incluso allí donde nos parecen oscuros y casi forjados por una voluntad totalmente orientada hacia el mal» (77).

Este lenguaje de la ficción -código de códigos- U. Eco parecía descartarlo de su horizonte de escritor: puede ser que a lo largo de mi vida un buen día decida escribir también una novela, porque puede suceder de todo. No le escondo que la idea podría parecerme divertida. $Y$ respecto a la estructura de la misma: si yo debiera escoger entre formas literarias, no ensayísticas, escogería a la parodia, el pastiche, más que la narración tradicional (78).

Colocados ante esta criatura, la novela, no prevista en el año 1977 , creemos poder aventurar -como lector libre, lector modelo, destinatario comprometido en la producción textual - una serie de hipótesis para comprender la estructura actancial, semántica o pragmática (el texto es un artefacto con artificios expresivos que el destinatario debe actualizar): hipótesis histórico-política, hipótesis cultural-científica, hipótesis científica, hipótesis policiaca, hipótesis religiosa.

Desde esta aparente pluralidad podremos acercarnos a una lectura más próxima al lector modelo, a una lectura global, donde se supere una estructura narrativa, para establecer — con una mirada semióticatoda la serie de indicios que nos hacen del autor-emisor textual un intérprete, subspecie semioticae, de la cultura-sociedad medieval; intérprete-lector de un texto base o referente: la sociedad, la economía, la política y la mentalidad medievales, interrelacionadas entre sí o de-

(76) ECO, U. (1982 a): El Nombre de la Rosa, Ed. Lumen, Barcelona, pp. 605-606.

(77) ECO, U. (1982 a): p. 17.

(78) PANCORBO, L. (1977): pp. 90-91. 
terminadas, según el modelo histórico elegido, por alguna de estas instancias.

Por supuesto, todas estas hipótesis pueden ser probadas indiciariamente en "El Nombre de la Rosa». M. Sito Alba ha especificado suficientemente los elementos necesarios para una lectura de la estructura superficial de "El Nombre de la Rosa" como novela policíaca, anotando los tópicos, estilemas o clichés propios de la novela policíaca (lugares, nombres, acciones): ... se trata, dice, de una narración críptica, en sus distintos niveles de lectura. Parecería lógico que el tipo de lector medio, que sólo busca en las novelas un pretexto para pasar el rato, no se interease en ella. No es así. Toda la trama argumental está concebida dentro de una estructura de talante policíaco, que apasiona lo mismo al ingenuo que al sofisticado. Lo que para uno es elemento esencial, para el otro resulta un juego de humor, de recuerdos de topoi del género (79).

Para una lectura histórico-política, el mismo autor aporta algunos datos: el cuadro en el que se desarrollan las peripecias de "ll nome della rosa" es rigurosamente histórico. Más que una reconstrucción muerta del pasado, es una vivencia actual, en la línea de las obras de una Marguerite Yourcenar o de un Robert Graves. Aparecen en forma directa las luchas entre el papado y el imperio o las corrientes religiosas o políticas de la época (80).

Lo mismo ocurre con una posible lectura centrada en el fenómeno ciencia-técnica: igualmente nos ofrece un panorama de la ciencia medieval en geografía, botánica, política, historia, teología. Los recientes y en cierto modo nuevos inventos de aquel momento que se iban popularizando, o se iniciaban, les dan a sus utilizadores en la novela una sensación de modernidad, casi de futuro, como las gafas, la pólvora, el reloj, el papel, el astrolabio, la brújula o la aplicación del mundo matemático de Averroes (81).

Se propone, incluso, material para una lectura prospectiva: Eco nos devuelve el mundo medieval en forma viva, amena y divertida. Asalta la tentación de buscar en medio de aquel complejo período claves de nuestro presente. Se podría pasar a un juego de identificaciones y de paralelismos, desde los grupos anárquicos, en su versión medieval de espirituales, a la lucha de la facción italiana de la Iglesia frente a la

(79) SITO ALBA, M. (1982): p. 42.

(80) SITO ALBA, M. (1982): p. 44.

(81) SITO ALBA, M. (1982): p. 44. 
incorporación de extranjeros en los altos puestos, empezando por el papa. Los partidarios de la violencia como solución de los males y los contrarios a ella (82).

En el ámbito de "lo dicho" frente a "lo no dicho", encontramos material para una lectura religiosa-apocalíptica: el Apocalipsis juega un papel esencial en la novela, tanto en su fondo como en su forma ... Algunos de los personajes que intervienen en "ll nome della rosa" tienen una mentalidad apocalíptica y a su vez el propio texto del apóstol amado de Jesús ayuda a descifrar algunos enigmas de la biblioteca eje del relato (83).

Nuestra decisión de lector va condicionada por el análisis de U. Ecoproductor que habla a través de estructuras narrativas, discursivas e ideológicas, aunque se coloque como el creador o manipulador de marionetas tras el escenario.

$U$. Eco está empeñado en leer la realidad semióticamente y, por supuesto, la literatura, el arte, etc. Su narración será uuna descripción de acciones que requiere para cada acción descrita una gente, una intención de la gente, un estado o mundo posible, un cambio, junto con su causa y el propósito que le determina; a esto podrían añadirse estados mentales, emociones, circunstancias; pero la descripción sólo es pertinente si las acciones descritas son difíciles y sólo si el agente no dispone de una opción obvia acerca de la serie de acciones que hay que emprender para cambiar el estado que no corresponde a sus deseos; los acontecimientos posteriores a esta decisión deben ser inesperados, y algunos deben resultar inusuales o extraños (84).

La estructura novelística como producto del autor es sólo una parte del texto: en la novela contemporánea, que tanto abunda en "no dicho" y en espacios vacíos, las previsiones del lector dependen de paseos mucho más azarosos (85).

Tanto «diccionario" como "enciclopedia» del lector nos obligan, en este caso - como complemento en la producción del texto-mensaje a minusvalorar o marginar esa estructura policíaca, porque su contenido, su realidad semántica está por encima del armazón meramente instrumental: frente a Fleming, que Eco define como «un cínico, un ingeniero

(82) SITO ALBA, M. (1982): p. 44.

(83) SITO ALBA, M. (1982): p. 45.

(84) ECO, U. (1981): p. 153.

(85) ECO, U. (1981): p. 168. 
de la narración de consumo", nuestro autor, presenta debajo de las voluntariamente tópicas estructuras narrativas, una ideología propia, clave de toda la obra (86).

Umberto Eco ha dicho del medievo en "Obra abierta" que: esta poética de lo unívoco y de lo necesario supone un cosmos ordenado, una jerarquía de entes y de leyes que el discurso poético puede aclarar en diversos niveles, pero que cada uno debe entender en el único modo que es posible, que es el instituido por el logos creador (87).

Ahí precisamente, en la Edad Media, sin necesidad de recurrir al modelo policíaco, en obras artísticas como "Le roman de la rose", las catedrales o los monasterios, puede encontrar U. Eco sus modelos de escritura.

U. Eco, conoce, como sustrato de su formación histórica, todo el material que la nueva historiografía medieval está aportando para realizar su visión, sin duda alguna revolucionaria, de la Edad Media. Además, como dice de él J. Lozano, «lo simbólico es, para Eco, una fuerza material como las relaciones de producción» (88).

Por todo esto, creemos que un marco histórico, geográfico, cultural, cronológico, de la ficción, como el que nos refleja «El Nombre de la Rosa» sirve para localizar una tesis de la Edad Media donde la dialéctica tradición-progreso está en pugna a estas alturas de la época medieval y se manifiesta —indicia- en el enfrentamiento, asumido por otra parte: razón-fe; religión-secularidad; inquisición-dogma-herejía; pecado-disfrute sexual; pobreza-ostentación.

Esta tesis se tematiza de un modo concreto: presencia de una legación de franciscanos por parte del emperador y de otra de miembros de la sede papal de Aviñón en una abadía italiana del siglo XIV para intentar pactos políticos (89). Legación que es relegada a segundo término al entrar en juego una trama interna de la abadia donde sucesivamente van desapareciendo (siendo asesinados) diversos monjes y descubriéndose comportamientos extraños en el ámbito del citado monasterio.

Según esta acotación, podríamos establecer como secuencias del relato las siguientes: encargo de la legación por parte del emperador y

(86) SITO ALBA, M. (1982): p. 44.

(87) ECO, U. (1979): p. 77.

(88) LOZANO, J. (1982): p. 49.

(89) ECO, U. (1982 a): pp. 353-366, 367-370. 
del papa, uno de cuyos integrantes (de la legación imperial) era Guillermo. Realización de la legación, dentro de la cual se enclava una nueva secuenciación, relacionada con la investigación de la vida anormal y asesinatos de la abadía; su estructura sería: encargo de la investigación, proceso investigador y resultado. Esta investigación del crimen tiene una estructura paralela, puesto que, siendo realmente Guillermo el encargado de la misma, en un momento dado, ante su fracaso, se encarga esta investigación a los legados pontificios. Por supuesto, aquí existe un doble resultado de la investigación criminal: fracaso aparente y posterior éxito de Guillermo y éxito aparente de la legación papal seguido de auténtico fracaso al confrontarse con el resultado "verdadero" de Guillermo. La tercera secuencia sería el resultado-fracaso a que se llega tras la reunión de ambas legaciones.

En las citadas secuencias, las funciones, actantes, acciones... vehiculizan la trama "la historia tal como de hecho se narra, tal como aparece en la superficie, con sus dislocaciones temporales, sus relatos hacia delante y hacia atrás, descripciones, disgresiones, reflexiones parentéticas. En un texto narrativo, la trama se identifica con las estructuras discursivas" (90) y la fábula «esquema fundamental de la narración, la lógica de las acciones y la sintaxis de los personajes, el curso de los acontecimientos ordenado temporalmente. No tiene por qué ser necesariamente una secuencia de acciones humanas: puede referirse a una serie de acontecimientos relativos a objetos inanimados $o$, incluso, a ideas" (91).

Guillermo es sujeto de la acción o acciones que definirá el relato, pero no constituye más que el pretexto para el discurso del autor $(E c o)$, a través del emisor interno (Adso) como narrador incluido en la trama: en el principio era el Verbo y el Verbo era en Dios, y el Verbo era Dios. Esto era en el principio, en Dios, y el monje fiel debería repetir cada día con salmodiante humildad ese acontecimiento inmutable cuya verdad es la única que puede afirmarse con certeza incontrovertible. Pero videmus nunc per speculum et in aenigmate...

$Y$ al final de mi vida de pecador, mientras, canoso y decrépito como el mundo, espero el momento de perderme... me dispongo a dejar constancia sobre este pergamino de los hechos asombrosos y terribles que me fue dado presenciar en mi juventud, repitiendo verbatim cuanto vi y of, y sin aventurar interpretación alguna, para dejar, en cierto modo,

(90) ECO, U. (1981): p. 146.

(91) ECO, U. (1981), p. 146. 
a los que vengan después (si es que antes no llega el Anticristo) signos de signos, sobre los que pueda ejercerse la plegaria del desciframiento (92).

Podrían ensayarse otras fragmentaciones o secuencias menos ligadas a un sujeto de acciones específicas y, en conformidad con la definición de fábula anotada anteriormente, secuenciar, por ejemplo, las fases del proyecto de modernización implícito en el texto: intento de modernización, oposición a la modernización, fracaso o éxito de la misma; también podríamos ensayar una lectura, más clásica en la novela gótica, en función del viaje: proyecto de viaje, realización del mismo y resultado final. Igualmente se podría secuenciar refiriéndonos a la búsqueda de la verdad, al problema de la herejía; al problema planteado en la biblioteca...

Desde este esqueleto superficial con apariencia de crónica, diario, diálogo, discurso, profecía, se dirigen (función del autor es provocar, dirigir, trazar indicios de lectura) manipulan o determinan nuestros pasos, a veces en forma de largas digresiones que rompen el ritmo, la univocidad, uniformidad y dogmática estructura de lo que hemos dado en llamar novela o relato, para ponernos en guardia y sembrar la duda que nos encamina a pensar —en línea con la novela contemporánea ya citada- en romper con la rigidez de los géneros en la producción o creación poético-narrativa.

Esta ruptura implica, en «El Nombre de la Rosa», la introducción de discursos, marginales o fundamentales para el desarrollo de la acción, pero, en cualquier caso, importantes para el emisor empírico que no sabemos si quiere hacer novela o, como anotamos anteriormente, un colage o pastiche, donde saque a relucir los temas, problemas o fantasías que le inquietan en torno a la Edad Media: herejía (p. 146-147, 271 ss.); milenarismo (p. 194); ciencia (p. 109-111); filosofía (p. 573, 46-48); arte (p. 410, 102-104); mujer (p. 308, 339), etc.

Una lectura del mundo medieval, visto retrospectiva o prospectivamente es el intento de Eco, con el cual quiere contribuir de forma particular a la lectura modélica o global del medievo hecha por los propios contemporáneos en «El roman de la rose», el Arcipreste de Hita, etc., o críticos del mismo desde otros momentos y modelos, esquemas o matrices ideológicas: Renacimiento, siglo XVIII, siglo XIX, etc.

(92) ECO, U. (1982 a): p. 17. En adelante las páginas de la novela las introduciremos dentro del texto por medio de paréntesis. 
Dada la focalización de nuestro trabajo en torno a la visión del medievo que podemos deducir, siguiendo los indicadores que nos aporta el propio autor-emisor-sujeto responsable del relato, hemos de centrarnos en los puntos claves que componen la estructura semánticopragmática de una narración: estructura, simbolismo y crítica de la realidad tematizada.

Sin duda alguna la microsociedad: "esta abadía es un verdadero microcosmos", que es el monasterio, refleja perfectamente la sociedad estamental y jerarquizada de la época feudal. Además, podemos encontrar los indicios suficientes para analizar los rasgos más significativos que caracterizan a cada uno de los tres órdenes que componen la sociedad de esta época: bellatores, oratores, laboratores o, siguiendo el propio texto: muchas veces había oído yo repetir la frase según la cual el pueblo de Dios se divide en pastores (o sea los clérigos), perros (o sea los guerreros) y ovejas (el pueblo). Pero más tarde he aprendido que esa frase puede repetirse de diferentes maneras. Los benedictinos habian hablado a menudo no de tres sino de dos grandes divisiones, una relacionada con la administración de las cosas terrenales y otra relacionada con la administración de las cosas terrestres. En lo referente a las cosas terrenales valía la división entre el clero, los señores laicos y el pueblo (p. 179).

De todas formas, el afán del narrador es poner en evidencia el mundo de los oratores, quizás en época de disolución o cambio: ¿Entonces, fray Guillermo, ya os habéis acostumbrado a esta cueva de locos?

Me parece un sitio habitado por hombres admirables en mérito, tanto a su santidad como a su doctrina - dijo cautamente Guillermo.

Lo era. Cuando los abades se comportaban como abades y los bibliotecarios como bibliotecarios... (p. 152, 48).

Encontramos alusiones al primer orden cuando se nos habla del origen del propio narrador, Adso: esta era la situación en el momento en que mi padre, que combatía junto a Ludovico, entre cuyos barones ocupaba un puesto de no poca importancia... (p. 20). Y, sobre todo, en las referencias hechas respecto al emperador que, según de donde proceda el juicio (Aviñón o franciscanos) será de uno u otro tipo, aunque a veces simplemente se constaten realidades históricas a fin de localizar - ¿objetivamente? - la historia: el señor me concede la gracia de dar fiel testimonio de los acontecimientos que se produjeron en la abadía cuyo nombre incluso conviene ahora cubrir con un piadoso manto de silencio, hacia finales del año 1327, cuando el emperador Ludovico entró en Italia para restaurar la dignidad del sacro imperio 
romano, según los designios del Altísimo y para confusión del infante usurpador simoníaco y heresiarca que en Aviñón deshonró el santo nombre del apóstol... (p. 17-19). Lo mismo ocurrirá con el papado, del que se habla en el momento de la localización histórica de la novela y posteriormente con otra serie de alusiones y juicios.

Las relaciones entre ambos poderes en ese momento histórico funcionaban, más o menos, del modo siguiente: en 1322 Ludovico el Bávaro derrotaba a su rival Federico. Si se había sentido amenazado por dos emperadores, Juan juzgó aún más peligroso a uno sólo, de modo que decidió excomulgarlo; Ludovico, por su parte declaró herético al papa (p. 19).

Los oratores hablan de sí mismos en estos términos: En lo referente a las cosas terrenales valía la división entre el clero, los señores laicos y el pueblo, pero por encima de esa tripartición dominaba la presencia del ordo monacarum, vínculo directo entre el pueblo de Dios y el cielo, y los monjes no tenían nada que ver con los pastores seculares que eran los curas y los obispos, ignorantes y corruptos, que ahora servían los intereses de las ciudades, donde las ovejas ya no eran los buenos y fieles campesinos sino los mercaderes y los artesanos. La orden benedictina no veía mal que el gobierno de los simples estuviese a cargo de los clérigos seculares, siempre y cuando el establecimiento de la regla definitiva de aquella relación incumbiese a los monjes, que estaban en contacto directo con la fuente de todo poder terrenal, el imperio, así como lo estaban con la fuente de todo poder celeste (p. 179).

Evidentemente, se impondría aquí considerar, desde fuera de la novela, la historia de las órdenes religiosas, monacales, mendicantes, etc., tal como la ha llevado a cabo G. Duby, L. K. Little Pacaut (93). Pero, en cualquier caso, estamos en un momento en que la ciudad está convirtiéndose en el centro de la vida socioeconómica y política, donde las órdenes urbanas están en pleno auge y los monasterios, de alguna manera, están entrando en crisis radical, como se evidencia simbólicamente en el trágico final de esta abadía (pp. 561-581): de las grandes y magníficas construcciones que adornaban aquel sitio, sólo habían quedado ruinas dispersas, como antaño sucediera con los monumentos de los antiguos paganos en la ciudad de Roma... El terreno estaba totalmente invadido por las plantas salvajes y ni siquiera se adivinaba

(93) DUBY, G. (1981); PACAUT, M. (1970), Les ordres monastiques et religieux au Moyen Age, Ed. F. Nathan; LITTLE, L. K. (1983): Pobreza voluntaria y economia de beneficio en la Europa Medieval, Ed. Taurus, Madrid. 
dónde habian estado el huerto y el jardín. Sólo el sitio del cementerio era reconocible, por algunas tumbas que aún afloraban del suelo ( $p$. 604).

Aun así, como el tiempo corto del relato acumula sintéticamente todo el acontecer medieval, podemos observar perfectamente lo que fue y cómo funcionaba la vida de un monasterio: los monjes, la economía, la cultura, los oficios, la vida cotidiana, las relaciones entre monjes y monjes y siervos.

El edificio nos es presentado con detalle en diversos lugares de la narración: mientras trepábamos por la abrupta vereda que serpenteaba alrededor del monte, vi la abadía. No me impresionó la muralla que la rodeaba, similar a otras que habia visto en todo el mundo cristiano, sino la mole de lo que después supe que era el edificio. Se trataba de una construcción octogonal que de lejos parecía un tetrágono (figura perfectísima que expresa la solidez e invulnerabilidad de la ciudad de Dios), cuyos lados meridionales se erguian sobre la meseta de la abadía... (pp. 29, 34-35, 420).

En cuanto a la economía se nos detalla la estructura de la tierra, haciendo ver el espacio socioeconómico de su extensión y dependencia: hay algunos prebendados que dependen de la abadía y comparten nuestra riqueza, en los años de abundancia ( $p$. 329); la riqueza, de la que hace alarde el propio abad: sí, la abadía es pequeña pero rica... (p. 45 ), dando a entender que la riqueza se extendía tanto a posesiones agrarias como a siervos, a joyas, etc.: ciento cincuenta servidores para sesenta monjes (p. 45); los vasos, los cálices, todo revelaba la materia preciosa con que estaba hecho... estas riquezas que veis y otras que aun veréis son la herencia de siglos de piedad y devoción y el testimonio del poder y la santidad de esta abadia (pp. 174-175). Contrasta, acaso con maligna intención de narrador, la comida en la abadía ( $p$. 120) y en la aldea vecina (p. 309).

Respecto a las relaciones sociales dentro del monasterio, habría que considerar diversos niveles: la cúpula de poder estaba en manos del abad (p. 543), tras el abad, el resto de monjes que desempeñaban oficios significativos: cillerero, bibliotecario, vidriero, herbolario (pp. 31, 37, 109-110, 46-48, 93, 134).

Debajo de los monjes estaban los siervos: ciento cincuenta servidores para sesenta monjes (p. 54), encargados de las más dispares labores: observé el trabajo de los vaqueros... de los porquerizos... de los pastores... de los labradores (pp. 344-345); poco después, escuchamos ruidos y, en un recodo surgió un grupo agitado de monjes y servidores (p. 31); a la derecha el albergue de los peregrinos y la sala capitular con 
el jardín; a la izquierda los trapiches, el molino, los graneros (p. 115).

De la abadía dependían, sin duda, algunas aldeas que cultivaban las tierras y aportaban rentas al monasterio: hay algunos prebendados que dependen de la abadía y comparten nuestra riqueza... (p. 329), según especificaremos a continuación.

La vida de la abadía estaba en función de la ordenación culturalreligiosa que imponía la regla benedictina (ora rezaban, ora estudiaban, ora comían...), pero a veces, y constituirá un dato importante para interpretar la novela, esta vida ordenada será transgredida radicalmente: no me detendré a describir cómo informamos al abad, cómo toda la abadía se despertó antes de la hora canónica... no sé si aquella mañana el primer oficio se celebró de acuerdo con las reglas, ni quienes participaron en él (p. 317).

Las relaciones existentes entre los miembros del recinto monacal están caracterizadas por la jerarquización, el orden, siempre símbolo de un orden cósmico impuesto por el creador, de modo que el abad manda sobre hombres, riquezas y espíritu en la abadía; cada monje es dueño de algún súbdito en el desempeño de los oficios, y, por supuesto, los monjes están sobre los servidores.

Ahora bien, para entender el proceso transgresor que está cindiciado" en el desarrollo de la narración es necesario no perder de vista algún tipo de relaciones anómalas en el ámbito de la abadía. Bien referentes a una "sexualidad desviada" entre los propios monjes: Berengario, como ya muchos monjes sabían, estaba consumido por una insana pasión cuyo objeto era Adelmo, la misma pasión que la cólera divina había castigado en Sodoma y Gomorra (p. 168), posible causa, al decir de algún monje, de la trama criminal que estaban contemplando o padeciendo. Igualmente, existían en el convento relaciones "prohibidas" de algún monje con aldeanas: porque la muchacha no iba con él por amor, sino por un paquete de riñones. Sin duda se trataba de una muchacha de la aldea, que, quizás no por primera vez, se entregaba a algún monje lujurioso por hambre... (p. 309); incluso el propio Adso, revelando quizás la transgresión más radical dentro de la moralidad del convento, pues no sólo gozó de la mujer, sino que comenzó a dudar de que tal cosa fuese pecado ¿no era criatura de Dios? (pp. 308 ss.).

En resumen, para poder entender la narración, conviene saber que, siguiendo un proceso deductivo y simbólico a la vez (lo que ocurre a nivel universal se reproduce y refleja en el particular) estamos presenciando una destrucción radical: Pero ¿qué estoy diciendo? Mira, en este país hace muchos años que suceden cosas vergonzosas, incluso 
en los monasterios, en la corte papal, en las iglesias... luchas por la conquista del poder, acusaciones de herejía para apoderarse de alguna prebenda ajena... (p. 513). En este contexto ha de comprenderse toda la intriga existente en la abadía en torno al poder (del abad, del bibliotecario, etc.) capaz, según alguno de los monjes y observadores, de producir los más horrendos crímenes.

Subraya $E$. Mitre que cel equilibrio y el buen funcionamiento de la sociedad cristiana había de basarse en las buenas relaciones y servicios reciprocos que se prestasen estos tres órdenes. En realidad - como sugiere P. Vilar- nos encontramos ante una imagen de la sociedad en que la base campesina alimenta a todo el conjunto y se ve gobernada por las superestructuras» (94), realidad patente en la sociedad medieval y en el microcosmos abacial, cuyo edificio socioeconómico se apoyaba en los siervos, por una parte (344-345) y en los campesinos de las aldeas por otra. Hambre, privación, falta de higiene, incultura, es la imagen que -dialécticamente- nos introduce Eco a través del narrador Adso: la aldea de abajo no es demasiado rica, ¿verdad? Si y no (pp. 329-330); esta situación social implicaba la degradación personal en algunos momentos: sin duda, se trataba de una muchacha de la aldea... que... se entregaba a algún monje lujurioso por hambre, obteniendo como recompensa algo en que hincar el diente, ella y su familia (p. 309). Esta realidad, por supuesto, era más general; de hecho, Salvatore recuerda, hablando de su infancia: una infancia muy penosa en una aldea donde el aire era malsano, las lluvias excesivas y los campos pútridos, en medio de un aire viciado por miasmas mortíferas (p. 227).

Frente a este orden, más o menos jerarquizado, podemos ir leyendo - diversos indicios nos to manifiestan - signos de una realidad nueva que se está fraguando fundamentalmente en torno a la ciudad, donde las relaciones sociales se organizan de otra manera, donde el saber forma parte de otros planteamientos y derroteros en el aspecto filosófico, científico y hasta religioso. Para los monjes, la ciudad significaba un peligro evidente en su organizada vida: yo creo que fue por eso que muchos abades benedictinos, para afirmar la dignidad del imperio frente al poder de las ciudades... (donde los obispos y los mercaderes se habian unido) (p. 179).

La ciudad que se nos ofrece en “El Nombre de la Rosa» se definiría con estas características: ¿Qué hacen hoy los italianos, que ni siquiera

(94) MITRE, E. (1982): Historia de la Edad Media, I, Ed. Alhambra. Madrid. 
tienen un papa? Comercian, y fabrican, y son más ricos que el rey de Francia (p. 153). «En Italia la ciudad no es como en mi tierra... no es sólo un sitio para habitar: es un sitio para tomar decisiones. Siempre están todos en la plaza, los magistrados de la ciudad importan más que el emperador o que el papa... Son... reinos aparte.

$Y$ los reyes son los mercaderes" (p. 155).

Sea como fuere, la ciudad alberga, en el relato, un germen imprescindible para la quema final de la biblioteca. Es decir, posibilita la promoción de la razón como forma de pensamiento autónomo, como base de investigación fundamentada en el método inductivo: porque la verdadera ciencia no debe contentarse con ideas, que son precisamente signos, sino que debe llegar a la verdad singular de las cosas ( $p$. 387 ); apoya la tecnologia $y$, sobre todo, pone en crisis la autoridad absoluta del libro; en la ciudad se busca y cree en la libertad y, por lo mismo, se pone en crisis la estructura jerarquizada del saber intensivo: explicación y conocimiento de la Biblia lo más profundamente posible como único libro digno de ser estudiado.

En este sentido, la abadia está en guardia ante el descubrimiento del material científico o, al menos, las bases de los planteamientos científicos que se albergan o entrometen en su recinto: Bacon, Ockham, Averroes... ponen en peligro la fe, según ciertos habitantes del monasterio, como la ponen los franciscanos, los dominicos, etc., en cuanto hombres de la ciudad. De todo ello tenemos prolijas alusiones en «EI Nombre de la Rosa" así como referencias a otras ciencias en germen y a las prácticas previas a cualquier establecimiento de la ciencia (medicina, farmacia, etc.).

La biblioteca, una de las más famosas en todas las abadías de la cristiandad; única luz que la cristiandad puede oponer a las treinta y seis bibliotecas de Bagdad, a los diez mil códices del visir lbn al Kami... (pp. 46-47), es representación simbólica del saber monacal y, en cierta medida, del saber de la Europa medieval anterior al siglo XIV y alberga en su recinto un contenido prodigioso de ciencia laica y ciencia religiosa, resaltando la gran colección de textos apocalípticos (p. 384). Ahora bien, este saber estaba custodiado rigurosamente, no todos podían entrar en ella y, cuando entraban, no podian leer todos los libros, a no ser que voluntariamente corriesen el riesgo de perecer: porque no todas las verdades son para todos ( $p .50$ ).

La ciudad, un lugar de libertad, tal como hemos dicho, significaba el riesgo más grande para este planteamiento del saber únicamente al alcance de las élites, prerrogativa casi exclusiva de clérigos y podero- 
sos: sólo domina quien sabe, quien tiene información. Los que sabian leer y escribir en aquel momento eran, sin duda alguna, muy pocos $y$, por tanto, privilegiados de la información y del poder. La ciudad, para los monjes, representaba, pues, lugar corrupto y anuncio de tiempos duros, difíciles, apocalípticos (p. 48).

La ciudad, con su carga de secularización y laicismo, es base de fundadas razones para producir la quiebra del mundo medieval, estructura organizada a partir de la matriz ideológica del Dios ordenador y creador del universo.

Pero más riesgo que la ciudad representa la herejía, amenaza de la jerarquización secular y religiosa. Ella se ha convertido, en la narración de U. Eco, en tema fundamental, privilegiado en cuanto a espacio y, sobre todo, en cuanto a valor narrativo.

La carga de intensidad actancial se debe a dos razones. Primero, la condena inquisitorial de que se hacen merecedores tantos herejes contemporáneos como antiguos partidarios de herejía. Condena que, claramente, está basada en la arbitrariedad de quien ostenta el poder social, político o religioso: los herejes son hechos por el poder, cuando necesita de ellos los apoya y cuando no, o bien los condena o deja que sean condenados (p. 247). Con ello la novela evidencia el riesgo o la evidencia de la manipulación de realidades en que se basaba dicha sociedad, tales como la propia fe, la religión o la iglesia. Los simples son engañados o manipulados respecto a la herejía y después sufren las consecuencias (pp. 243, 465).

En segundo lugar, la herejía, en cualquier momento, es la puesta en crisis del poder: religioso, político, o ambos. Precisamente, entre las herejias que aquí se analizan, se insiste mucho en los fraticelli, cuyas exigencias fundamentales son la pobreza evangélica y la igualdad social.

Evidentemente, no puede el papado, cargado de un triple poder: tres coronas, el poder espiritual, el poder temporal y el poder eclesiástico (p. 360), admitir una crítica que evidencie la inexistencia de un precepto evangélico fundamental para la Iglesia como es la pobreza: que la herejía de los que han predicado y predican la pobreza - dicen los legados de Aviñón- sólo puede conducir a actos criminales (p. 465). Como tampoco puede escuchar sermón alguno en torno a la igualdad quien en este momento sabe que: la constitución del pueblo de Dios se reduce a un gran rebaño de ovejas buenas y ovejas malas, vigiladas por unos mastines, que son los guerreros o sea, el poder temporal, el emperador y los señores y guiadas por los pastores, los clérigos, los intérpretes de la 
palabra divina... Pero... los pastores luchan con los perros, porque unos quieren tener los derechos de los otros (pp. 243-244).

La efectividad actancial-ideológica de esta herejía se apoya en lo anteriormente citado, pero su significado en el programa narrativo proviene de que la figura de Guillermo, anteriormente inquisidor, posesor de la verdad, dogmática, descubre sus propias dudas ante una realidad que estuvo, en algún momento, encargado de condenar (p. 65). Franciscano, que, junto a su legación $y$, quizás sobre todo, buscaba la verdad (pp. 20-21), se ha encontrado con una serie de verdades empíricas o realidades: lucha por el poder en el monasterio, condena arbitraria de unos herejes, explotación de una serie de personas de la aldea, encubrimiento culpable de la verdad.

La visión que intenta ofrecernos Umberto Eco respecto a la vida medieval, jerarquizada a partir de una matriz religiosa dominante, es, sin duda, el enfrentamiento de los representantes de la modernidad: defensores de la ciencia, de la crítica, del razonamiento, de la pugna frente a las fuerzas estáticas que implica el poder (papal, imperial, abacial) establecido. Por supuesto, esto no significa el triunfo de esta vertiente, sino la mera dialéctica que posiblemente no pueda aun surtir efecto: la modernidad no encontraba el soporte socioeconómico que la vehiculizase.

De ahí surge el final del relato, enclavado, quizás marginalmente, en la secuencia final de la legación: la abadia debe quemarse, pero los partidarios de la "verdad» en absoluto deben triunfar, al máximo podrán permanecer como indicios de lo que será la modernidad.

La realidad presentada es ésta, pero lo más interesante en esta visión semiótica de la realidad medieval es su presentación simbólica, a fin de provocar una lectura indicial del lector y, a la vez, para seguir la lógica del discurso cultural de la Edad Media: me dispongo a dejar constancia... de los hechos asombrosos y terribles... sin aventurar interpretación alguna, para dejar a los que vengan después signo de signos sobre los que pueda ejercerse la plegaria del desciframiento (p. 17).

El simbolismo citado tiene ámbitos de realización diversa: lectura prospectiva desde el Apocalipsis, microcosmos abacial, estructura arquitectónica de la abadía, de la iglesia, de la biblioteca, de la sala capitular.

La lectura apocaliptica es doble: textual e imaginaria (visual), puesto que el texto del Apocalipsis es el punto y lugar de referencia de lo que va sucediendo: demasiados muertos... Pero estaba escrito en el libro del Apóstol (p. 311); entonces comprendí que la visión hablaba preci- 
samente de lo que estaba sucediendo en la abadia (p. 59). Además, porque el final destructivo es, evidentemente, el final de un espectáculo dantesco de destrucción total: era la mayor biblioteca de la cristiandad... la abadía ardió durante tres días y tres noches y de nada valieron los últimos esfuerzos. No obstante acaso la destrucción del edificio, de la biblioteca, etc. no signifique más que destrucción de esas realidades materiales, ya que: quizás esta incapacidad para ver, producto de la sombra que la gran tiniebla que se aproxima proyecta sobre este mundo ya viejo, impida ver el auténtico fin.

Realmente, esta lectura simbólica pertenece al ámbito de lo pragmático, dentro de la narratología, puesto que la alegoría es el modelo medieval de lectura y el que se impone a sí mismo $U$. Eco en «El Nombre de la Rosa" y sobre el cual insiste constantemente: hay un arte secreto que permite nombrar con palabras análogas fenómenos distintos entre sí: es el arte por el cual las cosas divinas pueden nombrarse con nombres de cosas terrenales, y así, mediante símbolos equívocos, puede decirse que Dios es león o leopardo, que la muerte es herida, el goce llama, la llama muerte, la muerte abismo, el abismo perdición, la perdición deliquio y el deliquio pasión (p. 303).

De todos modos la pragmática de la obra se centra en los indicios que nos ponen en contacto con las voces narrativas (emisor, lector) y con el tiempo, elementos tan pragmáticos como ideológicos, puesto que significan fundamentalmente la introducción ideológica del emisor empírico junto al emisor interno de la narración.

Las voces de la novela, las miradas de la realidad, son múltiples aunque predomine la del clérigo-cronista-secretario-escribiente como autor-emisor objetivo, que constata (descubre o narra) una realidad que pasa ante sus ojos, por más que, modélica o paradigmáticamente, la lectura sea hecha por el clérigo: élite cultural en la época feudal. Las voces se multiplican para permitir hablar, para denunciar, predicar, divagar, profetizar, enseñar o condenar... al siervo, al predicador, al inquisidor, al legado..., personajes todos representativos del momento. De todas formas, por encima de todas esas voces está la del autor, cargado de objetividad ficticia, con su omnipresencia de bagaje enciclopediata.

La voz del narrador en primera persona, Adso, es la del sujeto de la narración dentro de la obra, que se nos presenta como un cronista, testigo presencial de los hechos, que intenta reflejarlos del modo más verídico posible: la verdad en él es una obsesión: tampoco esconderé, puesto que me he propuesto escribir siempre, y sólo, la verdad... (p. 352). 
Evidentemente, es una voz ideologizada, puesto que intenta dirigir al lector por medio de un proceso narrativo determinado: privilegiando unos discursos, identificándose con ellos, haciendo una lectura «a pie de página» que provoque el asentimiento del lector con respecto al que aparece juzgado como débil ante el poder arbitrario y dogmático ( $p$. $465,467,473$ ), manifestándose cómplice o interlocutor de la realidad con ayuda de Guillermo (p. 463). Su voz, realmente, se va construyendo paso a paso para llegar a la conclusión o relectura de la historia que vivió y no entendió ni siquiera al final de su vida, cuando únicamente refleja perpeljidad (p. 606).

Junto a la voz cronística de Adso aparece otra voz, igualmente ideologizada: la voz de la Escritura, bien como juez de la realidad: son realmente pobres los que imitan el Evangelio, justos los que reproducen la voluntad del Creador... o bien, con registro prospectivo, la manipulación del Apocalipsis para anticiparse a los hechos o para juzgar el porvenir.

El tiempo del relato es, igualmente, un tiempo de la cultura medieval: las horas del dia, la festividad de los santos para el calendario, constituyen el afán por resaltar el "tiempo de la Iglesia», "de la religión» frente a cualquier otro, sencillamente como el marco que encuadra el poder de Dios creador dueño de la realidad: el manuscrito de Adso está dividido en seis días y cada uno de estos períodos correspondientes a las horas litúrgicas (95).

El valor narrativo de este tiempo surge, como en el caso de la herejía, de su eficacia para presentar una transgresión. Es decir, el recinto monástico, signo de una realidad religiosa por excelencia, ha roto en el corto espacio de una semana el tiempo "del descanso" repetidas veces, para convertirlo en el "tiempo del crimen" y "de la intriga". Un dogma medieval: el orden día-noche y, con ello, todo lo que implica la estructura ordenada semánticamente: luz-tinieblas, mal-bien, etc., ha sido igualmente transgredido y, debido a esto, las desgracias podrán irse sucediendo continuamente.

Junto a este tiempo transgredido, dialécticamente el narrador se enfrenta a la transgresión que supone aprovecharse, por medio de la explotación, del tiempo de los demás: los campesinos, sin duda alguna (p. 309), aparecen como las víctimas, puesto que su tiempo de trabajo

(95) CAMPORESI, P. (1980): al due volti del tempo. Calendario agrario e calendario urbano*, en Alimentazione, folclore, societa, pp. 179-200, Ed. Pratiche, Parma; LE GOFF, J. (1983). 
no les da lo suficiente ni para comer, mientras que sus explotadores, en el ocio, disfrutan de buena comida.

El tiempo apocalíptico, en fin, funciona como telón de fondo de lo que puede o va a suceder, pero igualmente transgredido, ya que los tiempos difíciles, duros, justicieros, en realidad -aquí entra la manipulación ideológica del emisor empírico- sirven para dar paso, al menos así queremos leerlo, a una hipótesis de modernidad.

"El Nombre de la Rosa", pues, nos aparece como una obra donde un narrador distanciado: el 16 de agosto de 1968 fue a parar a mis manos un libro escrito... (p. 9), nos conduce, de la mano de un narrador introducido en la propia obra, hacia una lectura de la Edad Media no como época oscura, que así se ha leído desde el Renacimiento hasta el siglo $\mathrm{XX}$, sino como el "locus" donde dialéctica, y hasta contradictoriamente, convive la modernidad y el progreso con la tradición y lo estático.

Se ha construido su relato con el soporte de unos actantes que ponen escena estas situaciones contradictorias y nos hacen presenciar una continua transgresión de lo que papado, abad, emperador querían imponer: tiempo, fe, creencia, orden, para dar paso a: progreso, razón, ciencia; de tal manera que el Apocalipsis, obra considerada marca fundamental de la tradición y la inercia medieval, se convierte en el fuego necesario, pero purificador, del pasado dogmático, estático y absurdo.

Es una lectura semiótica, porque la alegoría como elemento basado en una operación de sustituir realidades por símbolos y donde la realidad es también símbolo, que adquieren un significado en el proceso productivo de significación de toda una cultura, es el factor pragmático predominante y porque las realidades narrativas: actantes, situaciones, lugares son, simplemente, soporte para la lectura de un destinatario cuya responsabilidad es dar sentido a esta "obra abierta" (pp. 26, 34, 605). 